\title{
Kajian Place Attachment di Kampung Pecinan Tambak Bayan Tengah, Kota Surabaya
}

\author{
R Dimas Widya Putra \\ INDEPENDENT URBAN RESEARCHER \\ Alumni InSTITUt TEKNOLOGI SEPUluh NOVEMBER, SuRABAyA
}

\begin{abstract}
Sungai Kalimas bersama dengan sungai Pegirikan merupakan dua struktur yang berperan penting dalam membentuk permukiman di Kota Surabaya. Di sepanjang tepian sungai Kalimas dan sungai Pegirikan ini terdapat permukiman-permukiman awal yang kini disebut sebagai kampung lama. kampung lama (permukiman awal) di kota Surabaya pada mulanya mengandalkan keberadaan sungai Kalimas dan sungai Pegirikan sebagai sumber kehidupan dan transportasi. Salah satu dari kampung lama tersebut adalah Tambak Bayan, Tambak Bayan merupakan kampung dengan etnis tionghoa yang masih bertahan di tengah perkembangan jaman. Kampung yang terbentuk setelah ratusan tahun ini masih bertahan dalam pesatnya pertumbuhan perekonomian pada Kota Surabaya. Di dalam kampung Tambak Bayan banyak masyarakat yang memiliki keterikatan emosi yang kuat terhadap kampung. Tujuan penelitian ini yaitu identifikasi nilai sosial-budaya, budaya bermukim masyarakat, dan keterkaitan antara struktur dan fungsi bagian wilayah Kota Surabaya. metode penelitian yang digunakan yaitu mengunakan analisis deskriptif - kualitatif yang diperoleh melalui index chart untuk mengetahui aspek keterkaitan warga kampung terhadap Tambak Bayan dan teknik analisis diachronic reading digunakan untuk menelusuri aspek perubahan kampung. Dari serangkaian hasil analisis menunjukkan bahwa keterikatan tempat dipengaruhi oleh faktor kekerabatan berupa akar keluarga dan kedekatan posisi kampung terhadap faktor tarikan, antara lain : pasar dan tempat bekerja.
\end{abstract}

Keywords: Budaya bermukim, Index chart, Place attachment, Tambak Bayan

\section{PENDAHULUAN}

Sungai Kalimas bersama dengan sungai Pegirikan merupakan dua struktur yang berperan penting dalam membentuk permukiman di kota Surabaya. Pada sepanjang tepian sungai Kalimas dan sungai Pegirikan ini terdapat permukimanpermukiman awal yang kini disebut sebagai kampung lama.

Kampung Tambak Bayan merupakan sahal satu dari kampung lama di kota Surabaya, kampung dengan etnis Tionghoa yang masih bertahan di tengah perkembangan jaman. Kampung yang terbentuk setelah ratusan tahun ini masih ertahan di tengah-tengah kepungan pesatnya pertumbuhan perekonomian kota Surabaya. Di dalam kampung ini masih banyak masyarakat yang memiliki keterikatan emosi yang kuat terhadap kampung Tambak Bayan sebagai tanah leluhur.

Secara administrasi kampung Tambak Bayan berlokasi di kelurahan Alun-Alun contong, Kecamatan Bubutan, kota Surabaya. Adapun batas administrasi kampung Tambak Bayan adalah sebagai berikut :

a. Sebelah utara: jalan pasar besar.

b. Sebelah timur: berbatasan langsung dengan sungai Kalimas dan kampung Peneleh.

c. sebelah selatan: jalan kramat gantung

d. Sebelah barat: alun- alun contong

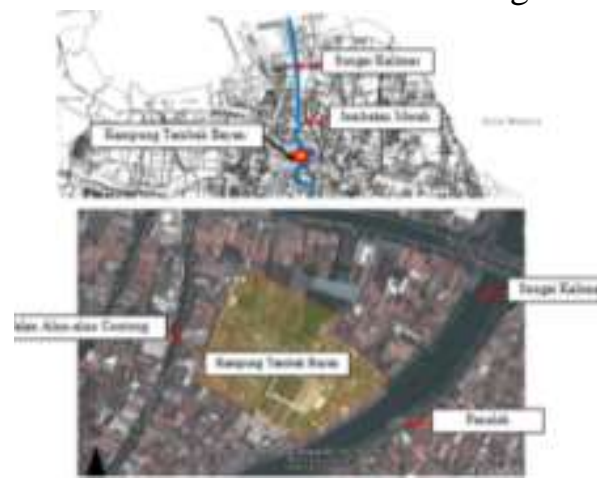

Gambar 1: Lokasi Penelitian 


\section{METODOLOGI}

Penelitian ini menggunakan pendekatan kualitatif dengan melakukan pendekatan langsung ke Masyarakat. place attachment adalah materi yang bersifat kualitatif sehingga diperlukan acuan indikator untuk mengkaji keterbentukannya. Menurut Mark Livington dkk (2008) Place attachment terbentuk oleh dua aspek, yakni aspek individual terkait usia profil penghuni, lama tinggal, rute kegiatan dan pengalaman dan aspek lingkungan terkait jaringan sosial, keamanan, dan stabilitas dari keragaman etnik.

Dalam mengkaji pokok pembahasan dalam penelitian ini dirujuk teori dari Lany Teddy dkk (2008) menyatakan bahwa terdapat 5 dimensi yang menbentuk place attachment, yakni :

a. continuity, terkait dengan pengalaman personal masyarakat terhadap tempat.

b. distinctiveness, terkait dengan pendefinisian identitas tempat oleh masyarakat.

c. attachment, terkait dengan emosi dan perilaku masyarakat terhadap tempat.

d. symbolism, terkait dengan interaksi hubungan nonfisik masyarakat dengan tempat.

e. familiarity, terkait dengan kenyamanan berkegiatan di dalam tempat.

Elisabeth Deane Brocato (2006) di dalam penelitiannya menyatakan bahwa terdapat 3 dimensi utama pembentuk place attachment, yakni affective component (affective attachment), cognitive component (place identity), dan behavioral component (place dependence, social bonds). Place identity adalah penggabungan tempat ke dalam konsep yang lebih besar dari diri, yang terbentuk berdasar teori identitas diri yakni cognitivedescriptive, affective-evaluative, object dan requirements. Place dependence adalah penentuan fungsi ruang terpilih yang bersifat relative, yang meningkat sejalan dengan waktu dan pengalaman dengan tempat. Affective attachment adalah eksplorasi respon emosional terhadap kondisi fisik tempat. Dan social bonding adalah mengenasi hubungan antar masyarakat dalam tempat tersebut. Adapun variabel yang dirujuk dalam penelitian ini dirangkum dari Endra Kusuma (2008), dapat dilihat dalam skematik berikut ini :

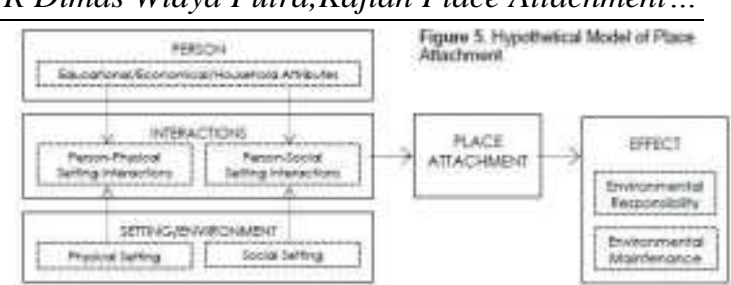

Gambar 2: Elemen-elemen pembentuk Place Attachment

Merujuk teori dan pemahaman tentang keterikatan masyarakat terhadap tempat, untuk itu diterapkan dalam metode penentuan responden berupa penggambilan sampling yaitu warga masyarakat yang telah bertempat tinggal di kampung Tambak bayan selama dua generasi dan memiliki pengaruh yang kuat di dalam kampung atau sesepuh kampung Tambak Bayan.

Dalam mengevaluasi sejarah perubahan dan perkembangan kampung digunakan analisis diachronic reading, yaitu penelusuran asal usul sejarah yang berkaitan dengan objek kawasan yang diteliti (Darjosanjoto, 2006) dalam hal ini kampung Tambak Bayan sebagai obyek penelitian

\section{PEMBAHASAN}

Kampung Tambak Bayan termasuk dalam kampung lama yang berusia ratusan tahun dan sudah ada jauh sebelum masa kolonialisasi Belanda. kampung Tambak Bayan sendiri berdiri sejak zaman penjajahan sekitar 1930-an, cikal bakal kampung Pecinan Tambak Bayan ini berawal dari sekitar 20-an orang dari China daratan Kanton, datang ke Indonesia. Mereka bermigrasi ke Indonesia melalui jalur laut, khususnya ke Surabaya karena sudah tidak nyaman lagi berada di negerinya. 20 -an orang Kanton itu mempunyai berbagai keahlian seperti tukang kayu, penjahit maupun ahli memasak.

Dengan perbekalan seadanya, mereka mengadu nasib di negeri orang yang sedang dalam masa penjajahan Belanda, Selama di kota Surabaya, mereka bertempat tinggal di gedung peninggalan Belanda di Tambak Bayan, Bangunan yang langit-langitnya tinggi dan terbagi beberapa ruang dan di bagian belakang terdapat pawon (dapur) dan kamar mandi, kabarnya dulu merupakan perkantoran bagi pegawai yang merawat kuda milik Belanda.

Untuk mengetahui awal pembentukan kampung Tambak Bayan, maka perlu dilakukan pembacaan sejarah (diachronic reading) dengan menyusun peta periodik kawasan dan membahasnya dalam satu 
komposisi kota Surabaya. Dapat dilihat pada gambar di bawah :

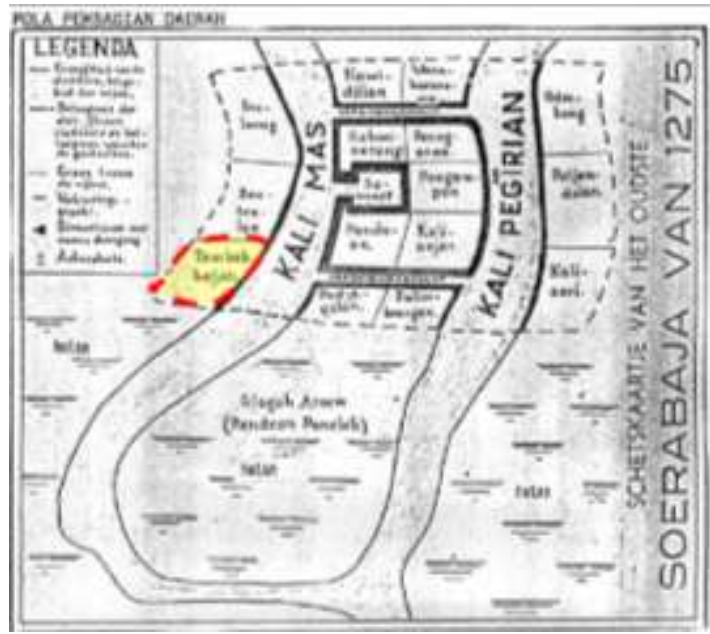

Gambar 3: Tambak Bayan Tahun 1275

Kampung Tambak Bayan sudah terbentuk sebagai gugusan pulau dan dikelilingi oleh hutan belantara, namun pada masa ini kampung Tambak Bayan belum dihuni oleh etnis Tionghoa melainkan masih daerah hunian Belanda. Dalam peta ini terlihat kampung-kampung lama yang tumbuh bersama Tambak Bayan, seperti: kampung Wonokusumo, Jagalan, Kalianyar, dan lainnya. Kelompok-kelompok hunian masih merupakan gugusan pulau-pulau yang tidak terhubung. Sehingga media air atau sungai berperan penting dalam mobilisasi atau pergerakan dari kampung satu ke kampung lainnya. Sedangkan dua sungai besar, yakni Kalimas dan Pegirian mengelilingi gugusan pulau dan kelompok permukiman awal. Pola jalan belum terlihat, ini menandakan bahwa kelompok hunian tersebar secara tidak terencana (irregular).

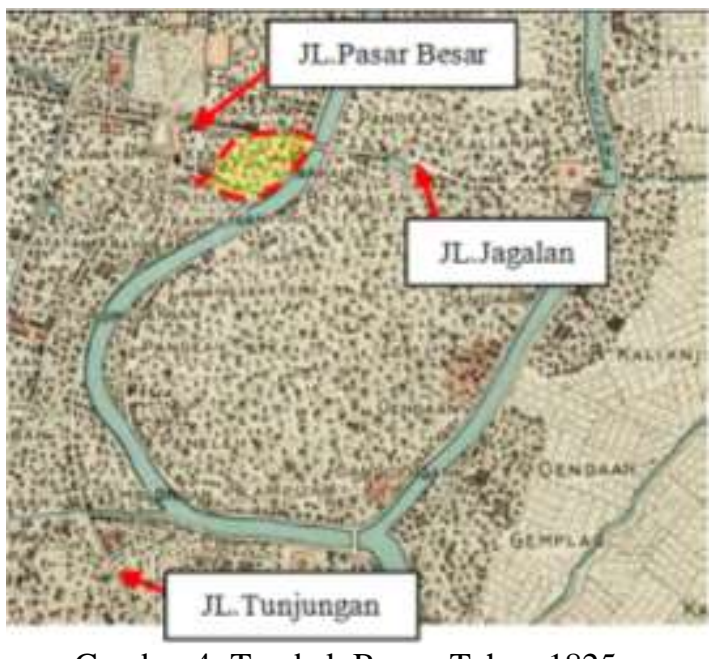

Gambar 4: Tambak Bayan Tahun 1825

Gugusan pulau-pulau kecil menjadi satu, namun keberadaan dua sungai besar masih sangat terlihat dengan jelas. Permukiman sudah meluas ke sisi selatan dan barat. Kampung Tambak Bayan sendiri sudah tumbuh dengan berdirinya beberapa kelompok hunian di tepi sungai Kalimas. Bentuk fisik kota secara luas tidak mengalami perubahan dari peta sebelumnya. Struktur jalan sudah terlihat antara lain jalan Jagalan, jalan Pasar Besar, hingga ke selatan jalan Tunjungan.

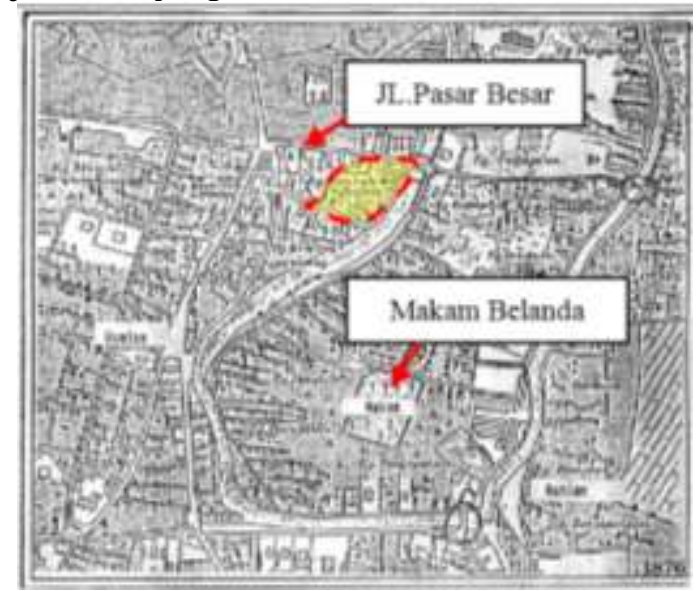

Gambar 5: Tambak Bayan Tahun 1876

Pada masa ini meskipun kampung Tambak Bayan sudah terbentuk namun tetap saja wilayah ini masih berupa rumah hunian pegawai Belanda baik yang berada di Tambak Bayan maupun kawasan sekitar berupa kota Tua karena pusat kegiatan masyarakat Belanda pada masa itu terletak di kota Tua dan sekitar Kalimas dengan terdapat Jembatan Merah, pada masa ini kampung Tambak Bayan sendiri merupakan kandang kuda untuk digunakan sebagai alat transportasi masyarakat Belanda, diseberang wilayah Tambak Bayan, tepatnya pada sisi timur juga terdapat makam Belanda, tepatnya di kampung Peneleh.

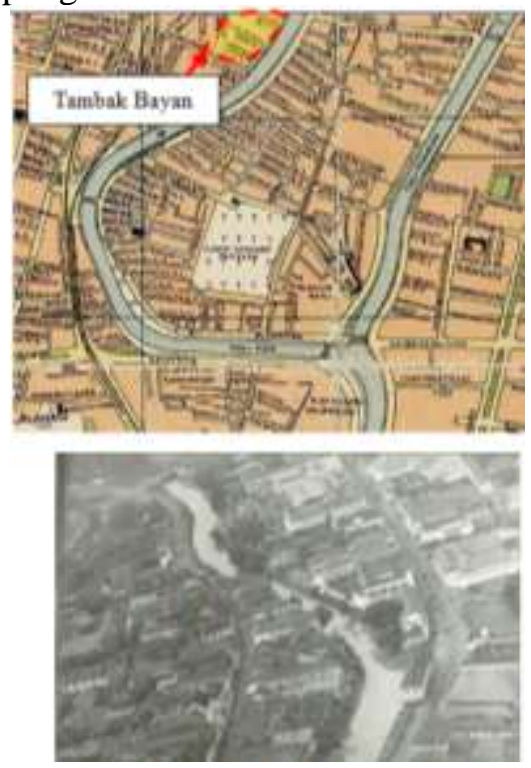

Gambar 6: Tambak Bayan Tahun 1934 
Pada masa ini merupakan awal mula bangsa China datang ke Kota Surabaya tepatnya pada tahun 1930-an, kemudian mereka bermukim di bekas kandang kuda dan bekas bangunan bermukim pegawai Belanda pada kampung Tambak Bayan yang terletak di sepanjang Kalimas, yang selanjutnya bekas kandang kuda dan bangunan Belanda tersebut dibenahi untuk dijadikan sebagai tempat bermukim, kemudian masyarakat China tersebut mencari teman-teman mereka yang sama-sama berasal dari daratan China untuk diajak bermukim di Tambak Bayan pada tahun 1938-an (Sumber : hasil wawancara dengan sesepuh kampung, yang berusia 82 tahun yang merupakan generasi kedua)

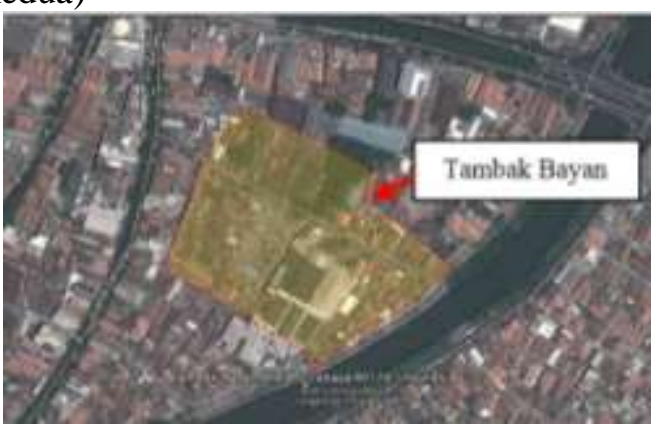

Gambar 7: Tambak Bayan Tahun 2015

Pada masa saat ini (hasil survey pada tahun 2015) unsur-unsur budaya sebagai kampung pecinan sudah sangat kuat pada kampung Tambak Bayan dengan ditemukannya bangunan-bangunan dengan kebudayaan China, seperti halnya tempat sembayang masyarakat China (dapat dilihat pada gambar 8), sedangkan elemen-elemen fisik pembentuk struktur kota tidak berubah. Menurut Rossi (1982) ini disebut dengan element of persistence. Elemen-elemen sebagai pembentuk kawasan adalah : sungai Kalimas, kampung-kampung di sekitar Tambak Bayan, bangunan China yang tumbuh untuk mendasari keberadaan kampung pecinan Tambak Bayan.

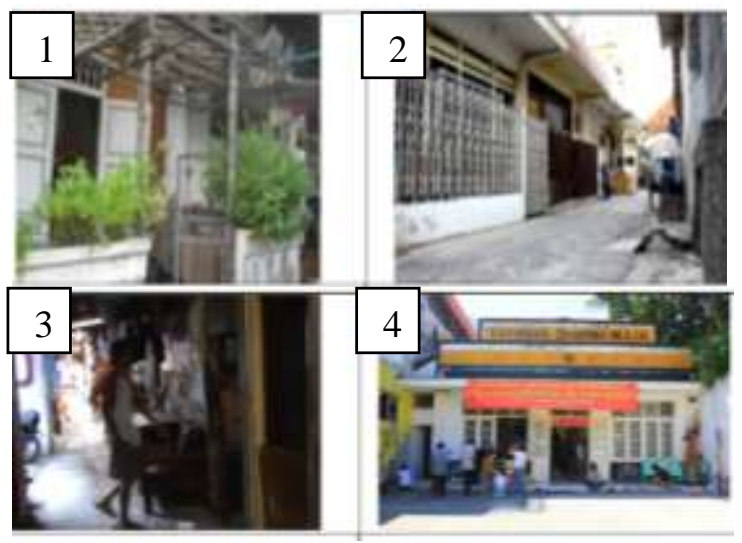

Gambar 8 Tipologi dan Karakteristik Bangunan
Tipologi rumah di kampung Tambak Bayan yang ditemukan pada lokasi studi dapat disimpulkan dalam keterangan sebagai berikut :

a. tipikal rumah memanjang ke belakang dengan lebar rumah sekitar $4 \times 3$ meter, $4 \times 5$ meter.

b. setiap rumah tidak memiliki halaman, melainkan hanya memiliki teras di bagian depan. Sebagai pengganti dari halaman rumah, sepanjang jalan gang merupakan tempat ruang bersama (sharing open space).

c. ruang-ruang dalam tersusun secara linier memanjang ke belakang.

d. terdapat beberapa bangunan dengan karakteristik bangunan masyarakat China, dengan pintu kayu tinggi dan terdapat hiasan hiasan simbol masyarakat China.

Untuk mengetahui data sosial-budaya masyarakat dan kegiatan masyarakat di dalam kampung Tambak Bayan, maka akan digunakan wawancara dengan sumber data yang diperoleh dari hasil quesioner (daftar pertanyaan ke responden) dan dirangkum dalam bentuk index chart. Berikut ini merupakan sampling index chart untuk menarik aspirasi masyarakat kampung

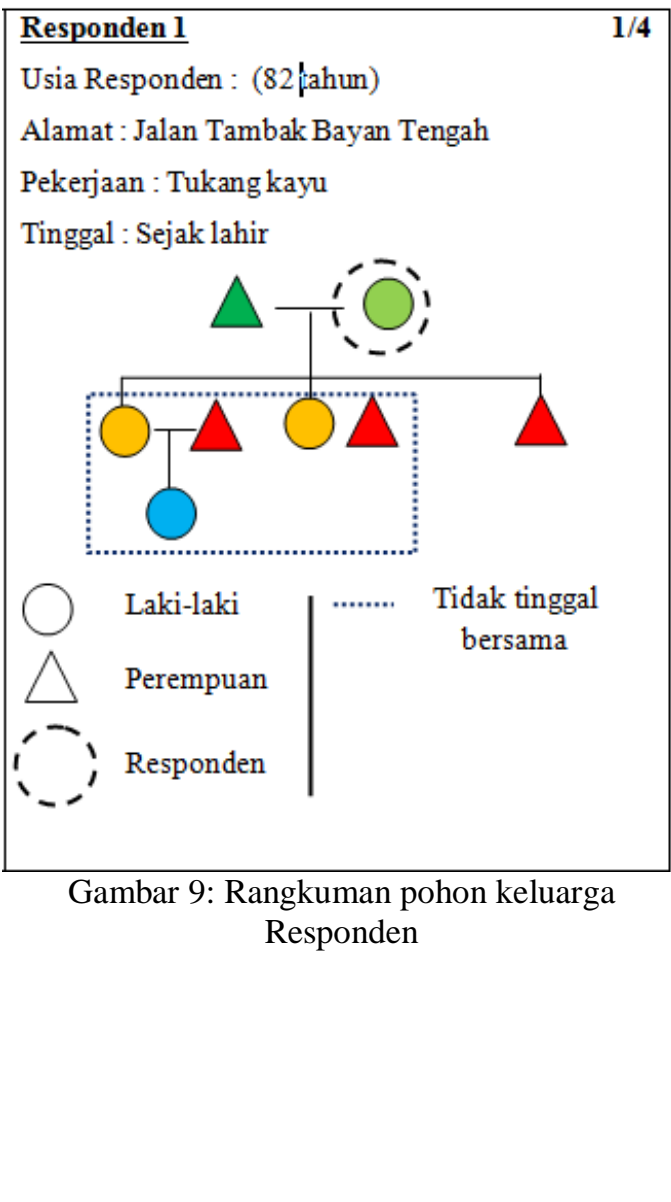




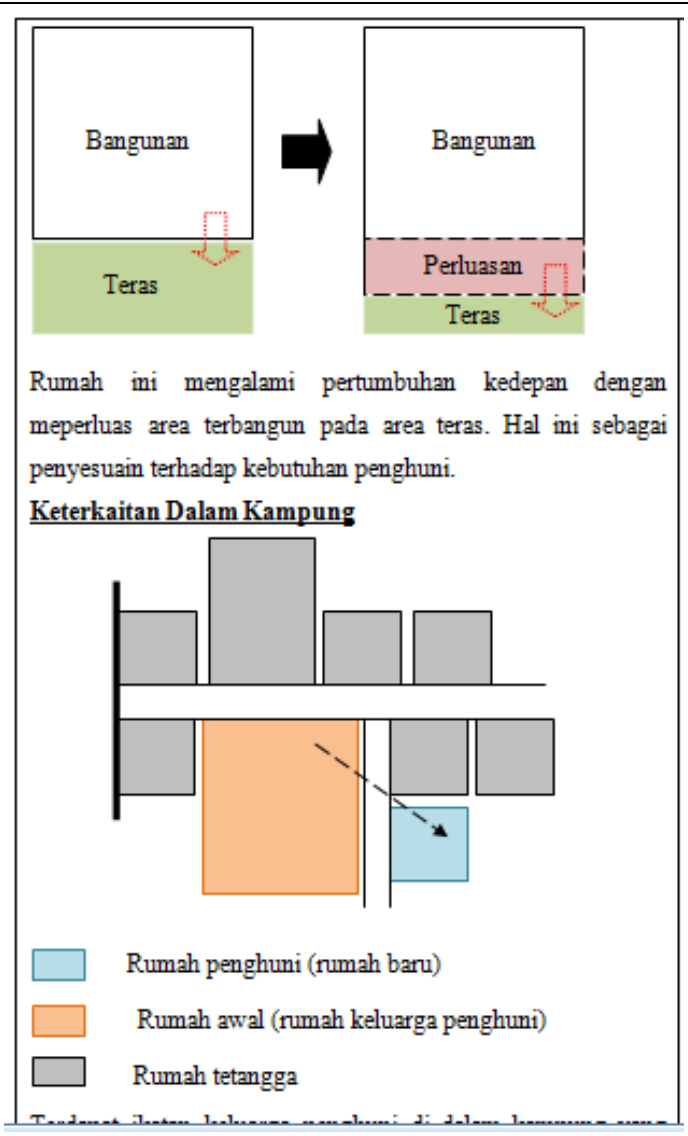

Gambar 10: Rangkuman sejarah pertumbuhan rumah asli

Dari index chart yang dilakukan terhadap 4 responden di dalam kampung Tambak Bayan, maka dapat kaitkan terhadap dua dimensi pembentuk place attachment (seperti yang telah dikaji dalam teori) :

1. Dimensi hubungan personal dengan fisik

- Responden-responden yang mewakili sebagai keseluruhan masyarakat kampung Tambak Bayan sebagian adalah pengerajin kayu, dan pembuat. Akses yang mudah dan lokasi strategis dari kompleks hunian kampung Tambak Bayan menuju pusat kegiatan dan perdagangan menjadi sebuah faktor kenyamanan masyarakat dalam berkegiatan.

- Adanya fasilitas publik untuk kebutuhan masyarakat di sekitar kampung Tambak Bayan menyebabkan adanya perasaan yang kuat antara penghuni kampung dengan kampungnya (people and spaces). Penghuni kampung merasa terfasilitasi atau dengan kata lain aktifitasnya telah terwadahi oleh adanya fasilitas publik yang ada di sekitar kampung Tambak Bayan, seperti : tempat berkumpul, tempat sembayang china, bangunan dengan karakteristik Tionghoa, lapangan, dan area perdagangan di sekitar kampung.

Masyarakat juga terfasilitasi dari kebutuhan fisik kawasan seperti : adanya jalan yang baik dan tidak bergelombang, saluran yang lancar, lampu penerangan di setiap sisi.

- Responden menyatakan bahwa sudah terdapat bangunan tempat bermukim yaitu bangunan Belanda yang merupakan bangunan secara turun temurun dari orangtua atau leluhur mereka dari dataran China.

2. Dimensi hubungan personal dengan sosial.

- Responden di dalam kampung Tambak Bayan sangat sadar bahwa kampung yang mereka diami telah berusia lama (masuk dalam kampung lama atau kuno Surabaya) dan memiliki bangunan peninggalan bersejarah dari periode kolonial (peninggalan fisik rumah tinggal yang masih bisa diamati hingga sekarang), dan jaman paska kemerdekaan (rumah-rumah atau tempat yang terpengaruh unsur etnis Tionghoa yang tinggal pertama kali tiba di kota Surabaya). Sehingga di kampung Tambak Bayan ini tersimpan banyak memori dari tidak hanya masyarakat yang tinggal di dalam kampung, melainkan juga masyarakat yang memiliki perasaan khusus pada kampung ini, bahkan terdapat penelitian yang dilakukan pada lokasi ini baik itu oleh orang Jepang melalui Japan Foundation maupun pameran seni oleh mahasiswa ITS, UNAIR dan PETRA.

- Hubungan masyarakat terjalin dari berbagai aktifitas rutin yang dilakukan di dalam kampung Tambak Bayan. Aktifitas yang dapat direkam dapat dibedakan dalam :

- Kegiatan bulanan: arisan pkk, rapat RT atau RW.

- Kegiatan tahunan: tasyakuran malam 17 agustus, lomba memperingati 17 agustus.

- Acara-acara informal seperti pameran seni dan mural (insidentil).

Dari rangkuman hasil analisis kualitatif melalui index chart, kemudian disimpulkan dalam bentuk pemetaan pergerakan keseharian yang biasa dilakukan yang terjadi di dalam wilayah penelitian, yang dijelaskan melalui gambar berikut ini : 


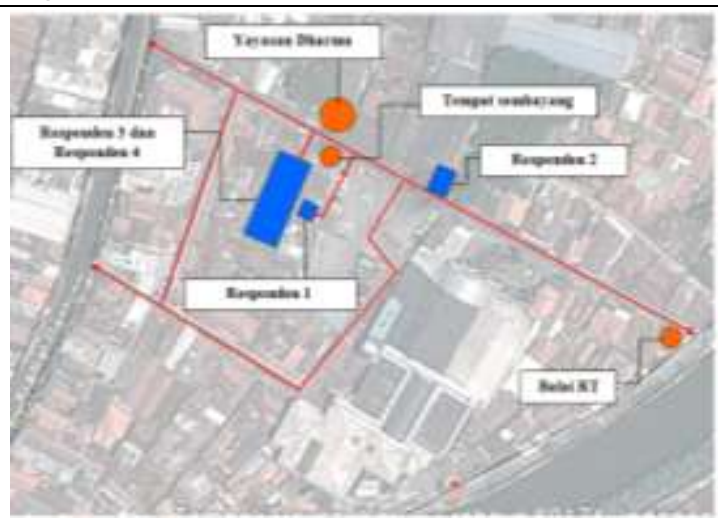

Gambar 11: Alur pergerakan masyarakat seharihari

Pada kampung Tambak Bayan ini, terdapat beberapa fasilitas publik yang memenuhi kebutuhan penghuni. Fasilitas publik lebih terfokus pada bagian kampung Tambak Bayan Tengah RT 5 karena terdapat beberapa sisa bangunan yang terletak berbatasan dengan sungai Kalimas, dimana sungai mempunyai peranan bagi masyarakat untuk kegiatan berkumpul dan rekreasi.

Adapun dalam skala yang lebih luas yaitu dalam kota Surabaya diketahui apabila keterikatan tempat memiliki peranan penting bagi pergerakan penghuni kampung bekerja belanja dan bepergian yang dapat digambarkan dalam peta pergerakan di bawah ini.

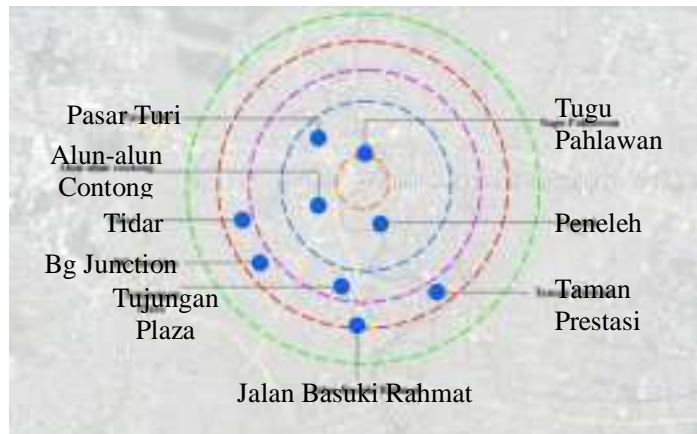

Gambar 12: Pergerakan penghuni kampung skala kota

Dalam skala kota, kampung Tambak Bayan memilki letak strategis yakni dekat dengan pusat kota dan fasilitas publik yang ada seperti Pasar Turi sebagai tempat berbelanja ibu -ibu rumah tangga, dan Jalan Tunjungan serta Tunjungan Plaza untuk kebutuhan belanja. Dan kampung ini berdekatan dengan toko-toko yang berada di sepanjang jalan Kramat Gantung, dikutip dari hasil wawancara dengan responden.

\section{KESIMPULAN}

Kampung Tambak Bayan ini memiliki place attachment yang kuat, di mana menurut definisi tingkatannya oleh Pindo Tutuko (2010), termasuk dalam tingkatan extention attachment. Hal tersebut disimpulkan dari kondisi masyarakat dari dulu hingga kini yang terus berganti-ganti penghuni, termasuk etnis di dalamnya yang kini didominasi etnis Tionghoa, namun terdapat percampuran pada saat ini tidak hanya etnis Tionghoa saja namun sudah bercampur dengan etnis Jawa. Namun tetap terdapat ikatan emosi yang terlihat dari penggunaan rumah secara turuntemurun oleh keluarga. Sehingga kondisi fisik kampung dijaga keasliannya, diantaranya fisik bangunan yang tetap menjaga gaya arsitektur era 1800-an, struktur ruang kampung dengan unsur China yang kuat, dan beberapa peninggalan sejarah seperti bangunan peninggalan Belanda bekas kandang kuda dan isunya terdapat bunker perang didalamnya.

Keadaan tersebut secara jelas dijabarkan melalui analisa dimensi pembentuk Place Attachment yang terbagi menjadi dua, yakni:

1. Dimensi hubungan personal dengan fisik

Pada kampung Tambak Bayan, dimensi ini muncul dari fasilitas publik yang ada di kampung yang dapat mewadahi kebutuhan penghuni, diantaranya tempat sembayang, yayasan Budi Dharma, lapangan, balai RT untuk berkumpul, dan pertokoan keramat gantung yang dekat dengan kampung tersebut (Place Dependence). Selain itu, dimensi tersebut terbentuk dari perilaku penghuni yang tetap diarea tersebut dengan tetap menjaga kenangan mereka, yang merupakan kenangan sejak lahir, diantaranya dengan tetap menjaga kondisi fisik bangunan rumahnya bergaya arsitektur era 1800-an dan tetap menjaga bangunan Belanda bekas kandang kuda walaupun terdapat perubahan ruang (Affective Attachment).

2. Dimensi hubungan personal dengan sosial

Pada kampung Tambak Bayan, dimensi ini muncul dari interaksi sosial penghuni dengan tetap menjaga tradisi lama seperti "imleg", terkait sejarah kampung yang kuat dengan bagaimana masyarakat bermigrasi hingga sampai pada kampung tersebut, dan kebiasaan sehari-hari dalam kegiatan berkumpul masyarakat bagaimana bekerja bersama sebagai pengerajin kayu dan pembuat pagar serta memasak bersama, namun Tambak Bayan ini pada saat ini belum dimunculkan oleh pemerintah Kota Surabaya sebagai salah satu kampung pecinan awal di 
kota Surabaya, karena justru kampung ini terancam digusur berbeda halnya dengan kampung seberang Peneleh yang sudah dilestarikan sebagai kampung cagar budaya, namun kampung Tambak Bayan ini berpotensi sebagai kampung cagar budaya karena sejarah yang kental dan keunikan kampung yang masih terjaga hingga kini (Place Identity).

\section{DAFTAR PUSTAKA}

Brocato, E.D. 2006. Place Attachment: An Investigation of Environments and Outcomes in A Service Context. Arlington: The University of Texas

Darjosanjoto, Endang Titi Sunarti. (2006), Penelitian Arsitektur di Bidang Perumahan dan Permukiman, ITS Press, Surabaya.

Kusuma.H.E,. 2008. Working Base and Place Attachment. ArtePolis 2 International Conference and Workshop. Bandung.

Livingston, Mark, dkk. 2008. People Attachment to Place - The Influence of Neighbourhood Deprivation. Chartered Institute of Housing

Tutuko, Pindo. 2010. Community Attachment pada Transformasi Desain Bangunan Pemukiman di Sekitar Kawasan Pecinan. Local Wisdom vol II Hal 10-19 
